\section{3 蜩電図データ処理の試み}

\author{
○西田 镕明, 险上 秀伯 \\ 讯田 正道, 馬場 正明（長崎大） \\ 司東 丕現, 津村 勝吉 (三采湘器)
}

加算平均処理方式の攀入によってヒトからも AP, SP, $\mathrm{CM} の$ 三種の蝸牛電気現家が記録されるようになり，蛤 電図法と呼ばれ，すでに広く臨床に応用されている。蝸 電図検查偪いて，指標となる項目が多ければ，本法か ら得られる情報量む增え，臨床的価値はたがると思わ れる。しかし，検㕿項目が多け狄ばそれだけ解折に多く の時間を要することになる.今回，われわれは螖電图の 自勒データ処理について検討したので報告する・なお自 動データ処 過程の一部を映画で供筧する。

\section{方 法}

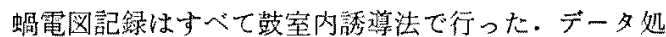
理はメモリ容星 $16 \mathrm{~K}$ 語を内藏した多目的データ処理装 置(シグナルフロセッサ， 7 T07 A，三栄測器）を使用 し，AP 処理用にプログラミングされたカセットテープ を用いて行った。即ち AP では設定回数たけ加算を行っ た後 $10 \mathrm{~dB}$ ステップでの加筹結果をメモりK記憶し.

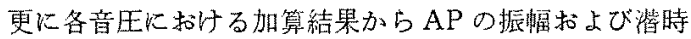
を自動的に計測し，特性曲線をブラウン管面上に表示で きるようにした、CM は本処理装置專用の標準プログラ 么 (AVERAGE 9301-100, 三桨測器) を使用し, 二次 処理にてフーリエおよび逆フーリエ夜撸を行った。

\section{結果と結語}

1) AP では各音生に和ける加算波形を1ページあた り4つの反応波形をブラウン管面上に表示し，X-Y レ コーダに鳥做図として配列記録することができた２） AP の特性曲線を $10 \mathrm{~dB}$ ステップでブラウン管面上に 表示することができた３） CMではノイズ成分が除去 された刺激音の周波数に相当した部分の反応を明嘹に㛟 出することができた。

多目的データ処理装䈯に AP 処理用プログラム就よ゙ 本装䁂薄用の標準プログラムを使用し $\mathrm{AP}, \mathrm{CM}$ の自動 データ処理を行ったが，処理プログラムはカセットテー プの塖入によって簡単に入力でき, 荘置の操作も籣単 で，短時間にデータ処理を行らことか゚できた。今回は主 にAPの特性曲線の表示を中心住報告したが，今後 SP, CM に関するデータ姏理についても検討していく予定で ある。

\section{4 图表表示対話処理方式による臨床的蝸電図検查法 とその臨床応用}

\author{
○吉江 信夫, 大橋 徹 \\ 司東 丕現, 木内 宗甫 \\ 新井骖（筑波大臨床医系）
}

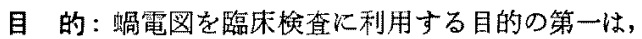
内耳機能梌查のためであり，聴力測定は副次的な利用方 法である.現在，ヒトの聴性電気反応のらら確信をる。 て難聴の診断に利用し得るるのは, 生理学的起源は, 才 ージオタトリー的な聴力測定の指標としてよりは耳科学 的な診断検查の指標として意義の方がはるかに大きく重 要であることを最初に強調したい、今後，蝸電図は，難 聴の診断，特に内耳機能検查の分野でをすます利用され てゆくものと考它られる。今回我々は，蝸電図を日常診 療の場で容易に利用できるよらにするため，図形表示詨 話処理万式の螖電計 システムを開発した。本システム

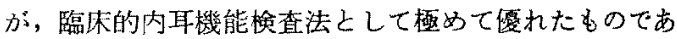
る囁を確認したので，本システムの特長とそれによる臨 林応用の成果学報告した。

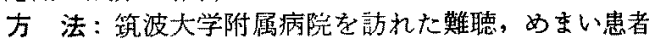
を対象として，鼓空誘導法に上り蝸電图家記録した。電 極装着は，キシロカイン，イオントフォレーゼ鼓膜麻醉 下に，我々が新たに開発実用化した螖電図電極固定装置

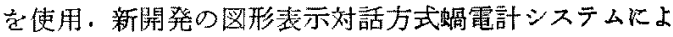
って, 蝸電図の記録，デー夕解折処理を夷施。本隐電計 システムは，必要とされる螖電困のあらゆる診断情報 (振幅, 潜時の入出力曲線, 波形パターン等) を自動的 に蒵早く，グラフ表示として読み出し，表示する能力が ある・

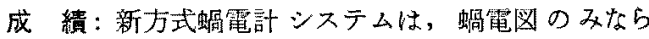
ず，あらゆる㯖性電気誘発反応の診断用データのダラフ はック表示に利用できた。しかし, 必要によって対話形 式により容易にデータ処理のブログラムを変更する事が できるので，臨不検查のみならず，研究のためのデー夕 解折処理が可能であり、データ処理のスビード化, 省力 化に極わて有効な重が判った・本システムによる臨床成 䒈をむ上めると，

(1) AP は Subtractive Loss の診断指標であった。 (2) SP は Sense-Organ Malfunction の診断指標であ った。（3） AP \& $\mathrm{SP}$ \&基底板上周波数領域依存性の 反応・゙ターンを示した。（4） CM の臨床応用は今後の問 題として揄討され就ばならない。

結 語：新方式蛹電計システムは，今度笑用化されれ 螖電図電極装着琵置と併用することにより極めて完成 度の高い他覚的内臣機能検查责施することができた。 今後, 本システムにより，伟電図の研究をさらに発展さ せてゆく考えである。 